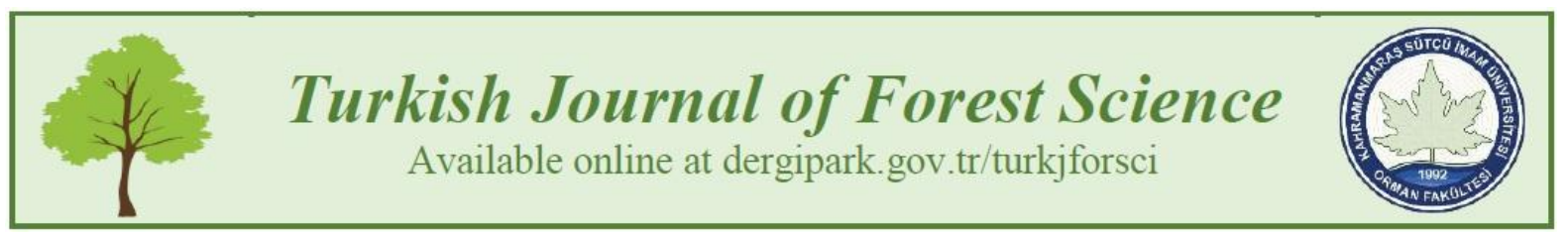

\title{
THE ROLE OF LANDSCAPE ARCHITECTURE ON SOUNDSCAPE EXPERIENCE
}

\author{
Sima POUYA* \\ Department of Landscape Architecture, Faculty of Forestry, Karadeniz Technical University, Trabzon, Turkey \\ *Corresponding author: sima_pouya2002@yahoo.com \\ ARTICLE INFO \\ Review \\ Received 10 September 2017 \\ Received in revised form 26 October 2017 \\ Accepted 31 October 2017

\begin{abstract}
Landscape design always refers to the construction of visual landscape environment, but human cognition of environment includes not only visual, but also acoustic cognition. In recent years, the soundscape was usually used as a key method to increase the sound quality in urban open spaces. Landscape factors have been considered in many previous studies in relation to sound and soundscape perception. Therefore, this aim of this research is to review the relationships between soundscape and landscape. This paper introduced the concept of soundscape, investigated sound envrionment of urban areas and explored soundscape elements and soundscape designs. In view of current sound environment features of open areas and different population groups' preferences for different sound elements, this paper proposed soundscape design method to improve sound environment of open areas.
\end{abstract}

Keywords: Soundscape, sound environment, urben open areas, landscape architecture

\section{İŞITSEL PEYZAJ DENEYIMIDE PEYZAJ MIMARLIĞININ ROLÜ}

\author{
ESER BILGISI \\ Derleme \\ Gelis 10 Eylül 2017 \\ Düzeltmelerin Geliși 26 Ekim 2017 \\ Kabul 31 Ekim 2017
}

ÖZET: Peyzaj tasarımı her zaman görsel peyzaj çevreyi fade eder, ancak insanların çevre bilinci sadece görsel değil aynı zamanda akustik bilişini de içerir. Son yıllarda, işitsel peyzaj genellikle kentsel açık alanlarda ses kalitesini artırmak için temel bir yöntem olarak kullanılmaktadır. Daha önceki birçok çalışmada, peyzaj faktörleri, ses ve işitsel peyzaj algıyla ilişskili olarak düşünülmüştür. Bu nedenle, bu araştırmanın amacı, işitsel peyzajın ve peyzaj tasarımları arasındaki ilişkiyi belirtmek amaçlıdır. Bu çalışmada işitsel peyzaj kavramı araştırılarak kentsel alanlardaki işitsel peyzaj elemanları ve tasarım ilkeleri ortaya konulmuştur. Sonuç olarak kentsel alanlarda mevcut ses ortam özellikleri ve farklı nüfus gruplarının farklı ses öğeleri için tercihleri göz önüne alındığında, açık alanlarda ses ortamını iyileştirmek için ses tasarımı önerilmiştir. 
Anahtar kelimeler: Işitsel peyzaj, ses ortamı, kentsel açık alanlar, peyzaj mimarlığı

\section{INTRODUCTION}

Soundscape as a concept was coined from the very beginning in close relationship with landscape (Schafer, 1969). Landscape factors have been considered in many previous studies in relation to sound and soundscape perception (Southworth, 1969; Viollon et al., 2002; Pheasant et al., 2008). Visual aspects of landscape in particular are thought to be closely related with soundscape perception in terms of experience of the surrounding spaces (Southworth, 1969; Kang, 2007; Pheasant etal., 2008; Joynt and Kang, 2010; Liu, et al, 2013). According to ISO, the soundscape is the acoustic environment as perceived or experienced and/or understood by a person or people in context (Meng \& Kang, 2016).

Soundscape is usually interpreted by means of identifying and describing different sound sources in a certain place (Brown et al., 2011). In the process of soundscape perception, how sensitive people are to specific sounds in the place and their preferences for these sounds are expected to affect their overall opinions of soundscape quality. This process could be affected by many factors as studied previously (Kang et al., 2012; Liu, et al, 2013). Specifically, in urban open spaces the effects of social, demographical and behavioural factors on soundscape perception have been widely analysed in terms of preference for sounds, subjective sound level evaluation and acoustic comfort evaluation (Yang and Kang, 2005a,b; Yu and Kang, 2008; Szeremeta and Zannin, 2009; Liu, et al, 2013).

There are kind of definitions of soundscapes in the literature (Table 1). "Soundscape is the subject of acoustic ecology and refers to both the natural acoustic environment consisting of natural sounds, including animal and sounds from trees, the sounds of water, weather, and environmental sounds created by humans through musical composition, sound design, and other human activities, including sounds of mechanical origin resulting from the use of industrial technology." (Rehan, 2016). As "soundscape can be defined as the totality of sound phenomena that lead to a perceptual, esthetic and representational comprehension of the sonic world." "Soundscape is thus an expression which focuses on the listener's experience of space" " and it refers to the acoustic environment at a place, like a residential area or a city park, as perceived and understood by people, in context. It is the acoustic equivalent to 'landscape,' and includes all sound sources, wanted as well as unwanted." (Rehan, 2016). "The soundscape approach includes management of the elements of the acoustic environment that are of high quality and value to people, either through acoustic design or by management of the outdoor space, much in the same way that landscape design is applied to improve visual perception of the environment." (Brown, 2010). Soundscape ecology is the study of sound within a landscape and its effect on organisms. "Sound forms an integral part of the urban environment, and there is a growing awareness that it should be considered at the same level of importance as visual aesthetics in the urban planning and design process.' (Coensel et al, 2010) And "a natural soundscape is an essential aspect of livability and quality of life.' (Rehan, 2016). 
Table 1. Definitions of soundscapes in the literature (Kuusiaho, 2016).

\begin{tabular}{lll}
\hline Southworth & $\mathbf{1 9 6 9}$ & $\begin{array}{l}\text { The acoustic properties of cities that help people relate to } \\
\text { space and activities occurring within the city. }\end{array}$ \\
\hline Schafer & 1977 & $\begin{array}{l}\text { Any acoustic field of study, e.g. auditory properties of a } \\
\text { landscape. Any defined acoustic environment. }\end{array}$ \\
$\begin{array}{l}\text { Krause } \\
1987\end{array}$ & $\begin{array}{l}\text { All of the sounds present in an environment at a given time. } \\
\text { Biophony includes sounds created by biological organisms, } \\
\text { and geophony nonbiological ambient sounds. }\end{array}$ \\
$\begin{array}{l}\text { Pijanowski, Farina, } \\
\text { Gage, Dumyahn, \& } \\
\text { Krause }\end{array}$ & $\begin{array}{l}\text { Complex arrangement of sounds from multiple sources- } \\
\text { including biophony, geophony and anthrophony-that } \\
\text { creates acoustical patterns in space and time. }\end{array}$ \\
\hline
\end{tabular}

Green areas can offer an escape and pause from the city environment, which is often considered - but accepted - to be hectic and noisy due to traffic and other anthrophonic sound sources. Since roads and traffic are presently unavoidable within cities, it is important to preserve spaces - such as urban green areas - where citizens are able to enjoy peaceful and natural soundscapes. Consequently, urban parks could be regarded as safe havens within a city, where people are constantly surrounded by accidental and unpleasant sounds, like vehicles and machinery. Soundscape of an urban park plays an important role in observing and experiencing nature, because the soundscape reveals information of the surrounding environment in 360 degrees (Krause 201; Kuusiaho, 2016)

Densely populated urban cities are often associated with the increase in traffic that leads to noise pollution (Raimbault \& Dubois, 2005; Goswami et al., 2011). One of the major contributions to noise emanates from the transportation sector (Anuar et al, 2017). With the regeneration of city centres, urban open spaces are reconceptualised with the new'urbanity' (Thwaites et al., 2005). Organisers of nature studies often find listening activities to be a good way of calming people and tuning them in to their environment. Children often need to be encouraged to listen to sounds, especially to more subtle ones. Consider both sounds that occur naturally and those that can be activated by people. Natural sounds include; leaves rustling in the wind, birds singing, water tricking/dripping/splashing, rain on an overhead cover. Activated sounds include; splashing water, striking chimes and sound sculptures. Deaf people will be able to sense vibrations and percussive sounds and these can be provided through sculpture and features such as deerscarers (Chinese tapping water features). "Sound fences", activated by dragging a stick along a series of lengths of tubing or piping are melodious and fun. To create a friendly environment, rethinking the urban landscape froman ecological viewpoint is important (Meng, 2016).

Therefore, this aim of this research is to review the relationships between soundscape and landscape. This paper introduced the concept of soundscape, investigated sound envrionment of urban areas and explored soundscape elements and soundscape designs. In view of current sound environment features of open areas and different population groups' preferences for different sound elements, this paper proposed soundscape design method to improve sound environment of open areas. 


\section{Urban Sound Classification}

The sounds were found to be in high correlation with people's landscape preferences, particularly the absence or presence of wanted and unwanted sounds, rather than acoustic features, e.g., A-weighted equivalent continuous sound level (Ren, 2015). Previous studies suggested that in a soundscape, natural sounds were often desired, whereas traffic noise and the sound of people's voices were undesired (Curcuruto et al, 2011; Nilsson et al, 2010) For example, hearing breeze and fountain sounds would significantly increase acoustic comfort, which added to the quality of the soundscape, but the mere presence of traffic sound, even at levels below the background sound level, had a negative effect on acoustic perception; moreover, in quiet areas, people may still be sensitive to road traffic sounds, even though the levels are probably considerably lower than those at roadside sites (Ren, 2015). Nature can be a source of information and experiences that can influence our everyday habits. In nature people can learn to fend for themselves and control their existence. It is considered to develop self-esteem, independence and benefit mental health. But noise can destroy the opportunities nature presents. The significance of nature and the cultural environment for humans is in many respects identical (Gottlob,1995).

"Urban sound classification is a method of describing the characteristic sounds and acoustic environments of cities. The method is intended to be used in urban analysis and thus in the preparation of supporting documents for the planning process and it is an effective tool in planning and urban design." (Wang, 2004). This method indicates that sounds may be generated by natural acoustics or by human-made acoustics (see Table 1). (Rehan, 2016).

When new projects are envisaged, and implemented, the management of landscape becomes a must, in a manner similar to that generally undrestood fort he landscape. This is more crucially so in urban environments where the complexity of activities will interefere with the also comples and varied exceptations of the urban population. In some places, one will require quiet and tranquillity; in others, one will like a varied soundscape related to one's particular activities; and in yet others, on emay even appreciate some mechanical sounds and urban vibracy that show how dynamic and active the city is. (Kang, 2007; Bayramoğlu et al, 2016a).

Architects, engineers, environmental experts, and urban technicians and planners may all be well intended and knowledeable in their Professional roles designing a new Project, be it a new urban development, a new transport infrastructure, or a new lesiure area, for example, but they frequently overlook its sonic component, that is, the sound environment that will be offered to the public space user. This might be serious issue in the final apparasial of the Project, as the soundscape must also be managed and planned, using adequate tools, to ensure that acoustic comfort is felt by the listener. Information and criteria regarding the degree of acceptance of the outdoor sound by the end users, basically the citizens, must be incorporated at the drawing board (Kang, J., \& Schulte-Fortkamp, 2016; Bayramoğlu et al, 2016b).

\section{The Natural Acoustics}

"Natural acoustics are sounds produced by natural sources in their normal soundscape, such as the sounds of any living organism." The natural acoustics of locations, which include reflections of sound, should be considered in the process of landscape planning. This source of sound may be generated by the physical environment (geophony) or by organisms (biophony) (Table 2) (Rehan, 2016). 
Geophony is the "sound generated from water, wind, rain, or other natural physical processes."' (Pijanowski et al, 2011). For example; the sounds of water, "since the sound of water in cities is soothing and therapeutic as well, it plays a powerful role in establishing the kind of quiet that is required; these paths should always connect up with the local pools. Rushing water can be used as an acoustic camouflage of traffic sounds. Paley Park in Manhattan is one such example. The original waterfalls still exist in many places and create seasonal water sounds. Because of this, the soundscape around these acoustic nodes can be regarded as a cultural heritage and thus important to preserve.' (Alvarsson et al, 2010).

Biophony is the "sound generated from non-human organisms." (Pijanowski et al, 2011). For example; the sounds of birds, the sounds of birds are important to soundscapes. Birds have been used as study organisms in much of the research concerning wildlife responses to human noise. Human-made acoustics Human-made acoustics are sounds generated from human activities (anthrophony) (Rehan, 2016).

Table 2. The sound sources (Kuusiaho, 2016).

\begin{tabular}{llll}
\hline & Biophony & Geophony & Anthrophony \\
\hline $\begin{array}{l}\text { Sounds } \\
\text { produced by }\end{array}$ & biological organisms & geophysics & humans \\
Examples & $\begin{array}{l}\text { Birds, insects, } \\
\text { amphidians mammals }\end{array}$ & $\begin{array}{l}\text { Wind, running streams, } \\
\text { rain movements of earth, } \\
\text { thunder, waves }\end{array}$ & $\begin{array}{l}\text { Machines, vehicles, } \\
\text { sirens bells, traffic, } \\
\text { music, language }\end{array}$ \\
& $\begin{array}{l}\text { signals are complex } \\
\text { because they carry } \\
\text { information }\end{array}$ & $\begin{array}{l}\text { driven mostly by climate } \\
\text { more common during } \\
\text { the daylight hours }\end{array}$ & \\
\hline
\end{tabular}

\section{Noise}

Sound is usually considred as noise if its loudness exceeds specific decibel value or the sound is detrimental for well-being. Noise is too described to be unwanted, unwelcome or random sound, which does not match into the existent circumference and for this reason, it bring stress and boredom. (Rådsten Ekman, 2015).

There are three several kind of noise; unwanted sound, unmusical sound (defined as nonperiodic vibration), and any loud sound." Noise may be-and often is-received unconsciously. According to Wissmann $(2014,1)$, the unawareness of noise in cities is caused by people accepting even disturbing sounds as an integral and inseparable part of an urban environment. As the cities are expected to be noisy, it may have led people to ignore their acoustic environment while being in a city (Kuusiaho, 2016; Rådsten Ekman, 2015).

In his book Geographies of Urban Sound Wissmann (2014, 55-56) has listed noise of an urban soundscape to include sounds from seven main sources, which are; motor vehicles, aircraft, railways, industrial and commercial enterprises, demolitions, construction, road works, racing tracks, amusement parks, night clubs, discotheques, and local human activities, such as noisy persons, slamming of car doors, lawn mowers (Kuusiaho, 2016). 


\section{Soundscapes And Well-Being}

The effect of sound on people is vast because sound is always present, since human ears are functioning continuously, even when asleep. According to Treasure (2009), sound is underestimated as a key element in quality of life although it affects people physiologically, psychologically and cognitively. In Table 3 some of the researched impacts of sound and noise on human health are presented (Kuusiaho, 2016).

Table 3. Impacts of sound and noise on human systems (Kuusiaho, 2016).

\begin{tabular}{|c|c|c|}
\hline & Health Impacts & Annotations \\
\hline Physiological & $\begin{array}{l}\text { changes in; } \\
\text { blood pressure } \\
\text { heart rate } \\
\text { depth and speed of breathing } \\
\text { muscle tension } \\
\text { hormone level } \\
\text { In addition; } \\
\text { hearing loss } \\
\text { tinnitus }\end{array}$ & $\begin{array}{l}\text { Often sort-term responses in automatic } \\
\text { nervous system. } \\
\text { Prolonged exposure may contribute to } \\
\text { numerous health problems, such as } \\
\text { increased probability of a heart attack. }\end{array}$ \\
\hline $\begin{array}{l}\text { Psychological and } \\
\text { CognitivePhysiological }\end{array}$ & $\begin{array}{l}\text { Annoyance } \\
\text { changes in emotional state } \\
\text { sleep deprivation and } \\
\text { disturbance } \\
\text { mental health problems } \\
\text { reduced cognitive processing } \\
\text { abilities } \\
\text { reduced productivity } \\
\text { memory impairment }\end{array}$ & $\begin{array}{l}\text { The level of the impact depends on } \\
\text { subjective appraisal. }\end{array}$ \\
\hline
\end{tabular}

Although, the physiological impacts are initially sort-term responses in automatic nervous system, prolonged exposure often contributes to various progressive and long-term health problems, such as cardiovascular and heart diseases. Alternatively, the level of the psychological impacts are experienced individually. The individual perception is discussed in more detail in the next section. According to World Health Organization, the psychological and cognitive impacts of noise affect a larger amount of people than the physiological impacts (Kuusiaho, 2016). Especially, cardiovascular effects are directly related to prolonged (low-level) stress, but also hearing impairments (including tinnitus) result from prolonged exposure to loud sounds. In addition noise causes other effects such as sleep disturbances and reduced work and school performance that can be alleviated or prevented with quietness (Andringa, \& Lanser, 2013).

Sound does not only have negative health impacts, since a peaceful and harmonic soundscape can also cause positive physiological and psychological changes. For instance, most people find many natural sounds - such as bird song and waves - reassuring and soothing, which is likely to lead to decrease in blood pressure and stress level. As already discussed, increasing the amount of positively connoted sounds is a more efficient and potential way to improve the overall soundscape quality than noise abatement. In order to know, how sound could be used as a resource for enhancing the positive impacts, it is important to examine how sounds are perceived and how they make people feel (Kuusiaho, 2016). 


\section{Soundscape Planning}

The famous landscape architect Ian McHarg (1969) described the process of landscape architecture partly as the synthesising of layers of information. His overlay techniques help in weighting together interests in the landscapes. One of the layers was the information of sounds in the landscape in terms of noise (Hedfors, 2003). The soundscape of a place is simply its sonic, or acoustic, environment, with the receiver, or listener, at the centre of the sonic landscape. Schafer argued, amongst other matters, that soundscapes are amenable to analysis and design. To him, acoustic design meant discovering the principles by which the aesthetic qualities of the acoustic environment may be improved. These principles could include elimination or restriction of certain sounds through noise abatement, the preservation of sounds that give character or sense of place to a location (soundmarks as the acoustical equivalent of visual landmarks) or imaginative placement of sounds to create attractive and stimulating environments (Hedfors, 2003).

Acoustic design of outdoor space should be seen as complementary to noise management, abatement or control. Noise management is the current paradigm for management of the outdoor acoustic environment, involving a large body of knowledge, practice, law, policing and control activities and most municipal authorities and provincial governments are active in this to varying degrees. Noise control in urban areas deals largely with 'sounds of discomfort' - sounds that disturb sleep, interfere with communication, distract or annoy people. Limits to these sounds are based on acceptable risk, and noise abatement seeks to minimise negative effects on people in high exposure situations. These negative effects are well known, as are the levels recommended to limit them. By contrast, soundscape planning focuses on acoustic environments that are regarded positively - that people prefer or consider as desirable environments (Hedfors, 2003).

Soundscape planning, by analogy with landscape planning, involves design or management to manipulate the acoustic environment of a place in a way that results in improved human perception of its environment. At present, environmental noise control approaches may be utilized within the planning and design of such areas, but various authors have shown how it is possible to significantly expand the inclusion of acoustic considerations beyond the adverse effects of noise to the positive elements of soundscape planning-enhancing human experience of the acoustic environment of any place (Hedfors, 2003).

\section{Noise Control}

There is a difference between noise control and soundscape planning in the locus of application, though in this difference there is more overlap. Noise control uses three strategies for action: control at the source, management of the transmission path between source and receiver, and protection of the receiver (Hedfors, 2003). Trees and other vegetation can play an important role in attenuating noise through reflecting and absorbing sound energy (Table 4). One estimate suggests that $7 \mathrm{db}$ noise reduction is achieved for every $33 \mathrm{~m}$ of forest whilst other reported field tests show apparent loudness reduced by $50 \%$ by wide belts of trees and soft ground (Dwyer et al, 1992). 
Table 4. List of trees can play an important role in attenuating noise through reflecting and absorbing sound energy

\begin{tabular}{ll}
\hline Abclia grandi Flora & Cedrusdeodara \\
Abies balsamea & Cedras Libani \\
Abies bomolepsis Lawsoniana & Chamaecyparis \\
Abies fraseri & Cotoneaster sp. \\
Abies lasiocarpa arizonica & Cryptomeria japonica \\
Abies magniFica & Cu pressus arizonica \\
Buxus sempervirens & Elaeagnus pungens \\
Cedrus atlantica & Euonymus japonicas \\
Euongmus patens & Pinus monticola \\
Euongmus radicans canierei & Pinus mugo \\
Ilex crnata & Pinus nigra \\
Ilex glabra & Pinus ponderosa \\
Ilex opaca & Pinus radiate \\
juniperus chinensis & Pinus resinosa \\
juniperus commonis hibernica & Pinus strobes \\
juniperus excelsa & Pinus sylvestris \\
Juniperus scopulorum & Pyracantha coccinea \\
Juniperus virginiana & Squoiadendron giganteum \\
Kalmia LatiFolia & rhododendron sp. \\
Ligustram Lucidum & Sequoia sempervirens \\
Mohonia aquifolium & Taxus bacata \\
Picea glauca & Taxus cuspidate \\
Picea omorika & Thuja plicata \\
Picea orientalis & Tsuga Canadensis \\
Picea abies & Thuja orintalis \\
Picea pungens & Tsuga caroliniana \\
Viburnum rhytido phyllom & Tsuga betere opbylla \\
\hline
\end{tabular}

The impact of anthrophonic noise sources can be reduced by masking or covering them, but only reducing noise to an accepted level does not necessarily improve the overall acoustic environment. A more effective and proactive way to improve a soundscape is to add positively connoted sounds, because relative increase of pleasant sounds is discovered to decrease the perceived loudness and annoyance of the receivers (Kuusiaho, 2016).

Opening the ears in a garden expands the senses and broadens the garden encounter. Opportunities can be provided in a open area for sitting under a tree to hear the sound of wind rushing through the leaves. Many plants offer sounds with a small amount of wind or jostling: bamboo stems knock together, grasses rustle, palm fronds sway. Seed pods of some plants make natural maracas, or rattles. Leaves can be left on the ground to crunch underfoot. Sounds of animals enliven the senses. Oak trees can host squirrels that chatter and scramble. Birdsongs can fill the garden if bird baths, bird-attracting plants, bird feeders, and bird houses are provided and maintained (URL 1).

Lakes, ponds, pools, and puddles fall into the still-water category, that is, waters that are flat, static, and unmoving. Moving waters are waters that fall, flow, pour, and spurt, such as waterfalls, rivers, brooks, fountain jets, and cascades. In a way, water sounds are almost like music, varying in rhythm, volume, pitch, sharpness, softness, and harmony (Rådsten Ekman, 2015).

It has proven difficult to reduce the impact of traffic noise with water sound without generating a much louder water sound (Watts et al., 2009). Jeon et al. (2012) found that the 
acoustic features of fountains and water structures influenced the subjective perceptual response when combined with traffic noise, the introduction of water sounds being found to improve the acoustic environment (Figure 1). The preference scores for the water sounds were related to the adjectives "freshness" and "calmness," the former associated with high sharpness (i.e., high frequencies) and the latter with low sharpness (i.e., low frequencies). Water sounds with more sharpness were also considered more pleasant (Rådsten Ekman, 2015).

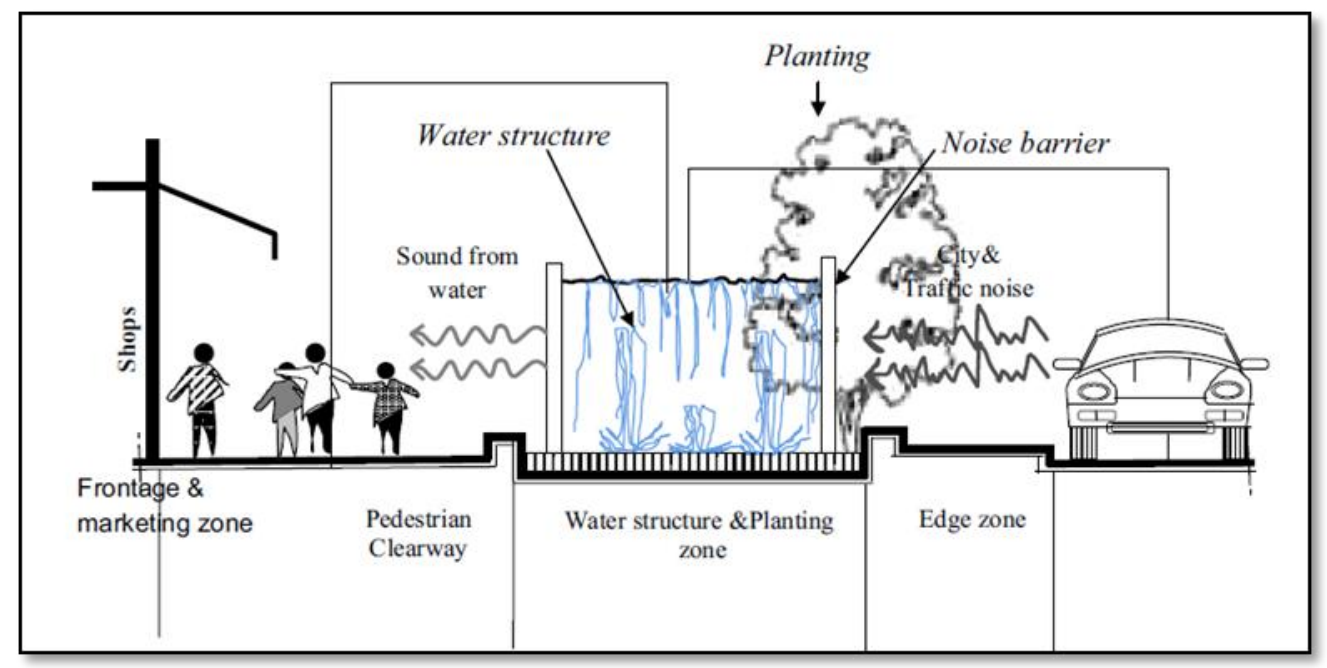

Figure 1. Water structure and planting (Rehan, 2016).

\section{CONCLUSION}

Urban soundscape is an important part of the phonic identity of a city in that sounds are essential in creating a sense of place. Schafer (1994, 268-269), in an international sound preference study, discovered that the most pleasant sounds were all natural sounds such as birds, rivers, and breeze. Therefore, it could be assumed that adding natural sounds into an urban environment could help to mitigate the experienced noise and improve the overall soundscape. One way to increase the amount of natural sounds in an urban environment is to have sufficient urban parks and green areas within a city (Kuusiaho, 2016).

The sounds were found to be in high correlation with people's landscape preferences particularly the absence or presence of wanted and unwanted sounds rather than acoustic features. To put it another way, natural sounds were often desired whereas traffic noise and the sound of people's voices were undesired. The soundscape in urban environments includes multiple sound sources and sound events. Sounds from nature are typically taken as a means to improve the acoustic quality of urban environments (Yang \& Kang, 2005b; Lam et al, 2010).

There is a difference between noise control and soundscape planning in the locus of application, though in this difference there is more overlap. Noise control uses three strategies for action: control at the source, management of the transmission path between source and receiver, and protection of the receiver (Hedfors, 2003). Trees and other vegetations might play an important role in attenuating noise through reflecting and absorbing sound energy. 
Soundscape design might pay attention to consideration as an important aspect of urban design (Rehan, 2016). The important opinion of this paper was to focus on the soundscape design of urban open spaces as part of the urban planning process. The notion of soundscape in urban open spaces was addressed in line with its definition, objectives, and classifications. The current research at last concluded that soundscape design would be a very important section of the planning process for urbans that are sustainable and lovely spaces to live.

\section{REFERENCES}

Andringa, T. C., \& Lanser, J. J. L. (2013). How pleasant sounds promote and annoying sounds impede health: A cognitive approach. International journal of environmental research and public health, 10(4), 1439-1461.

Anuar, E. M. E. M., Din, N. B. C., \& Hussein, H. (2017). Traffic Noise Influence on Soundscape Quality At Campus Landscape Area.Journal of Design and Built Environment, 17(1).

Bayramoglu, E., Akinci, Y. C., \& Demirel, O. (2016a). Interaction Between Urban Design And Ergonomics Of Fittings. Case Study Of Trabzon Coastal. Area. Journal of Environmental Protection and Ecology, 17(2), 711-718.

Bayramoglu, E., Demirel, O., \& Celik, K. T. (2016b). The Evaluation of Landscape Equipment Components in Terms of Ergonomics. Anthropologist, 25 (1,2): 151-159.

Brown Al, Kang J, Gjestland, T. (2011). Towards Standardising Methods İn Soundscape Preference Assessment. Appl Acous; 72: 387-92.

Curcuruto S, Asdrubali F, Brambilla G, Silvaggio R, Alessandro F D', Gallo V. (2011). Socio-Acoustic Survey And Soundscape Analysis İn Urban Parks İn Rome. In: Proceedings Of The 10th International Congress On Noise As A Public Health Problem, London, Uk.

Dwyer,J. F., Mcpherson, E. G., Schroeder, H. W., \& Rowntree, R. A. (1992). Assessing The Benefits And Costs Of The Urban Forest. Journal Of Aboriculture, 18, 227-234, Https://En.Wikipedia.Org/Wiki/Natural_Sounds.

Gottlob, D. (1995). Regulations For Community Noise. Noise News International, 3(4), 223236.

Hedfors, P. (2003). Sonic tools for landscape architecture. In Conf. proceedings "Acoustic Ecology", Australian Forum for Acoustic Ecology/World Forum for Acoustic Ecology, Melbourne, Australia (pp. 19-23).

Kakkori, S. (2016). Vuoden Pyöräilykaupunkiin Panostetaan-Suunnitteilla Yhdeksän Baanaa Jyväskylän Halki [The Cycling City Of A Year İs Well-İnvested-Nine Routes Through Jyväskylä Are Under Consideration]. Keskisuomalainen, 13 April 2016, 4-5.

Kang, J. (2007), Urban Sound Environment. London: Taylor \& Francis İncorporating Spon; 2007.

Kang, J., Schulte-Fortkamp, B. (Eds.). (2016). Soundscape and the Built Environment. CRC press.

Alvarsson, J. J., Wiens, S., \& Nilsson, M. E. (2010). Stress recovery during exposure to nature sound and environmental noise. International journal of environmental research and public health, 7(3), 1036-1046.

Joynt Jlr, Kang J. (2010), The Influence Of Preconceptions On Perceived Sound Reduction By Environmental Noise Barriers. Sci Total Environ;408:4368-75.

Kuusiaho, V. (2016). Soundscapes Of The Kehä Vihreä Urban Park. 
Lam, K. C., Brown, A. L., Marafa, L., \& Chau, K. C. (2010). Human preference for countryside soundscapes. Acta Acustica united with Acustica, 96(3), 463-471.

Liu, J., Kang, J., Luo, T., \& Behm, H. (2013). Landscape Effects On Soundscape Experience İn City Parks. Science Of The Total Environment, 454, 474-481.

Meng, Q., \& Kang, J. (2016). Effect Of Sound-Related Activities On Human Behaviours And Acoustic Comfort İn Urban Open Spaces. Science Of The Total Environment, 573, 481-493.

Nilsson Me, Alvarsson J, Rå Dsten-Ekman M, Bolin K. (2010), Auditory Masking Of Wanted And Unwanted Sounds İn A City Park. Noise Control Eng J 2010;58:524-31.

Pijanowski, B. C., Farina, A., Gage, S. H., Dumyahn, S. L., \& Krause, B. L. (2011). What is soundscape ecology? An introduction and overview of an emerging new science. Landscape ecology, 26(9), 1213-1232.

Pheasant R, Horoshenkov K, Watts G. (2008), The Acoustic And Visual Factors İnfluencing The Construction Of Tranquil Space In Urban And Rural Environments Tranquil Spaces- Quiet Places? J Acoust Soc Am , 123(3):1446-57.

Rådsten Ekman, M. (2015). Unwanted Wanted Sounds: Perception Of Sounds From Water Structures İn Urban Soundscapes (Doctoral Dissertation, Department Of Psychology, Stockholm University).

Rehan, R. M. (2016). The Phonic İdentity Of The City Urban Soundscape For Sustainable Spaces. Hbrc Journal, 12(3), 337-349.

Ren, X., \& Kang, J. (2015). Effects Of The Visual Landscape Factors Of An Ecological Waterscape On Acoustic Comfort. Applied Acoustics, 96, 171-179.

Schafer Rm. (1969), The New Soundscape: A Handbook For The Modern Music Teacher. Canada: Bm1, Don Mills.

Szeremeta B, Zannin Pht. (2009), Analysis And Evaluation Of Soundscapes İn Public Parks Through İnterviews And Measurement Of Noise. Sci Total Environ, 407: 6143-9.

Viollon S, Lavandier C, Drake C. (2002), Influence Of Visual Settings On Sound Ratings İn An Urban Environment. Appl Acoust; 63(5):493-511.

Wang, K. (2004). The aesthetic principles of soundscape in architectural design and built environment (Doctoral dissertation, Texas A\&M University).

Yang W, Kang J. (2005a). Acoustic Comfort Evaluation İn Urban Open Public Spaces. Appl Acoust;66(2):211-29.

Yang, W., \& Kang, J. (2005b). Soundscape and sound preferences in urban squares: a case study in Sheffield. Journal of Urban Design, 10(1), 61-80.

Yu L, Kang J.(2008), Effects Of Social, Demographic And Behavioural Factors On Sound Level Evaluation İn Urban Open Spaces. J Acoust Soc Am, 123(2):772-83.

URL 1. Sensory Gardens, Eva C. Worden and Kimberly A. Moore2, UF/IFAS Extension, Gainesville, FL 32611. http://edis.ifas.ufl.edu. 